\title{
Industrial and commercial opportunities to utilise concentrating solar thermal systems in South Africa
}

\author{
Alan Brent \\ Centre for Renewable and Sustainable Energy Studies, School of Public Leadership, Stellenbosch University \\ Marthinus Pretorius \\ Graduate School of Technology Management, University of Pretoria
}

\begin{abstract}
A solar energy technology roadmap has been developed for South Africa. The roadmap lists a number of technological systems that fulfil three requirements from a South African perspective. First, they have clearly been demonstrated or commercialised. Second, a local industry could be stimulated including the potential to export, with associate socio-economic growth; and the other requirements of government can be met in terms of improving energy security and access, and addressing climate change. Third, they have a medium to high $R \& D$ intensity, in terms of available capacity and associate resources needed to support the further development of the technological systems. Concentrated Solar Thermal systems feature prominently in the list of technologies. These systems can generate electrical power, then referred to as Concentrating Solar Power systems, typically in the 1 to $100 \mathrm{MW}$ range for on- and off-grid applications. They can also simply produce heat, typically in the 100 to $1000^{\circ} \mathrm{C}$ range, primarily for commercial and industrial process applications. This paper discusses the international trends and drivers for these systems to generate power and heat, and then focuses on the specific potential in the South African context. A number of barriers to realizing the potential are discussed and recommendations are made accordingly to stimulate the growth of this industry sector in South Africa.
\end{abstract}

Keywords: Technology Roadmap, solar energy, concentrating, developing countries

\section{Introduction}

South Africa has the major challenge of closing the gap between its first (developed) and second (developing) economies, while 'decoupling' the growth of the economy as a whole (see Figure 1). In other words, maintaining the growth with declining material throughput, and with associated benefits such as improving the carbon emissions balance of the economy (Brent et al., 2009). Further, to be globally competitive, and to make the transition towards a knowledge-based economy, will require innovation for sustainability and associated innovative development strategies. The support of appropriate technology research and development is core to such strategies. To this end, the South African national Department of Science and Technology has recognised the need to enable an emerging solar energy industry, which can address the challenge, and also contribute to energy resources diversification in the country. The response was a national project. The coordination and development of a national solar energy technology roadmap, through a multi-stakeholder process, was the second component of the larger project, which followed on a baseline study, and formed the foundation of a further feasibility study and a business plan for a Centre of Competence (DST, 2010).

The solar energy technology roadmap (SETRM) primarily aims to highlight key strategic research and development (R\&D) focus areas, and the required interventions by various role players to enable such R\&D. The goal of the SETRM is not to provide insight in terms of where the solar energy sector of South Africa should be heading, but where the national system of innovation (NSI) should place its emphasis to support and expand the emerging industry.

The SETRM specifically focuses on active solar energy systems, ${ }^{1}$ and excludes passive solar energy systems. ${ }^{2}$ The primary breakdown of the systems 


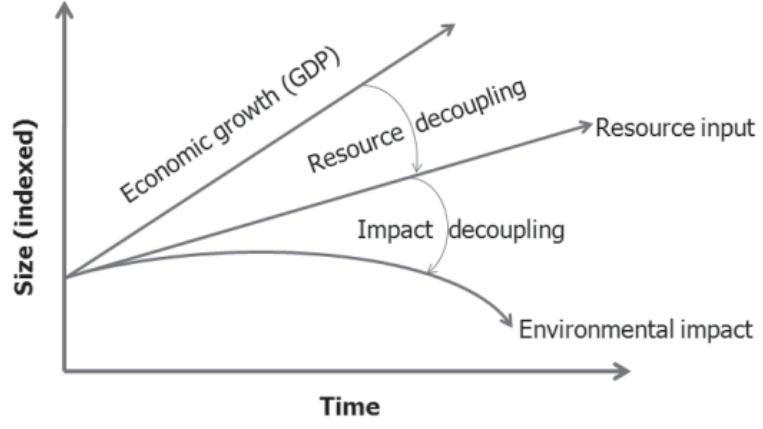

Figure 1: Representation of 'Upstream' and 'Downstream' decoupling

(Source: UNEP, 2009)

that are based on concentrating solar thermal technology platforms are summarised in Table 1, in terms of power and thermal as energy services, and including scale or temperature ranges.

\section{International market trends and drivers, and cost implications}

The global projections are that solar energy technologies will, overall, play a significant role in the future energy supply and demand landscape (REN21, 2009), especially beyond 2040 (see Figure 2).

The contribution of solar thermal applications may remain relatively small, but it is expected that solar power applications will, eventually, overtake the combined contributions of all other energy resources.

\subsection{CSP systems - Trends}

Two new concentrating solar (thermal) power (CSP) plants came online in 2008: the $50 \mathrm{MW}$ Andasol- 1 parabolic trough plant in Spain, and a 5 MW central receiver demonstration plant in California. These followed on three new parabolic trough plants during 2006/2007; the first in one and a half decades (see Figure 3). A number of additional projects came online in 2009/2010, including

Table 1: Classification of the concentrating solar thermal systems that form part of the SETRM (Source: DST, 2010)

\begin{tabular}{llrr}
\hline System service & \multicolumn{1}{c}{ System market / application } & \multicolumn{2}{c}{ System output } \\
\hline Power & Industry sector & Large & $>1 \mathrm{MW}$ \\
\hline & Municipalities / commercial clusters & Large & $>1 \mathrm{MW}$ \\
\hline Nhermal & National grid & Large & $>1 \mathrm{MW}$ \\
\hline & $\begin{array}{l}\text { Commercial buildings / agriculture sector / industry sector for } \\
\text { cooling (adsorption chillers, single and double action) }\end{array}$ & Medium & $130-180^{\circ} \mathrm{C}$ \\
\hline & $\begin{array}{l}\text { Municipalities / commercial clusters / industry sector for } \\
\text { desalination by multi stage flash (MSF) distillation }\end{array}$ & Medium & $90-120^{\circ} \mathrm{C}$ \\
& Industry sector for process heat & & \\
\hline & Industry sector for process heat & High & $<500^{\circ} \mathrm{C}$ \\
\hline Industry sector for thermochemistry and fuels & $>750^{\circ} \mathrm{C}$ \\
\hline
\end{tabular}

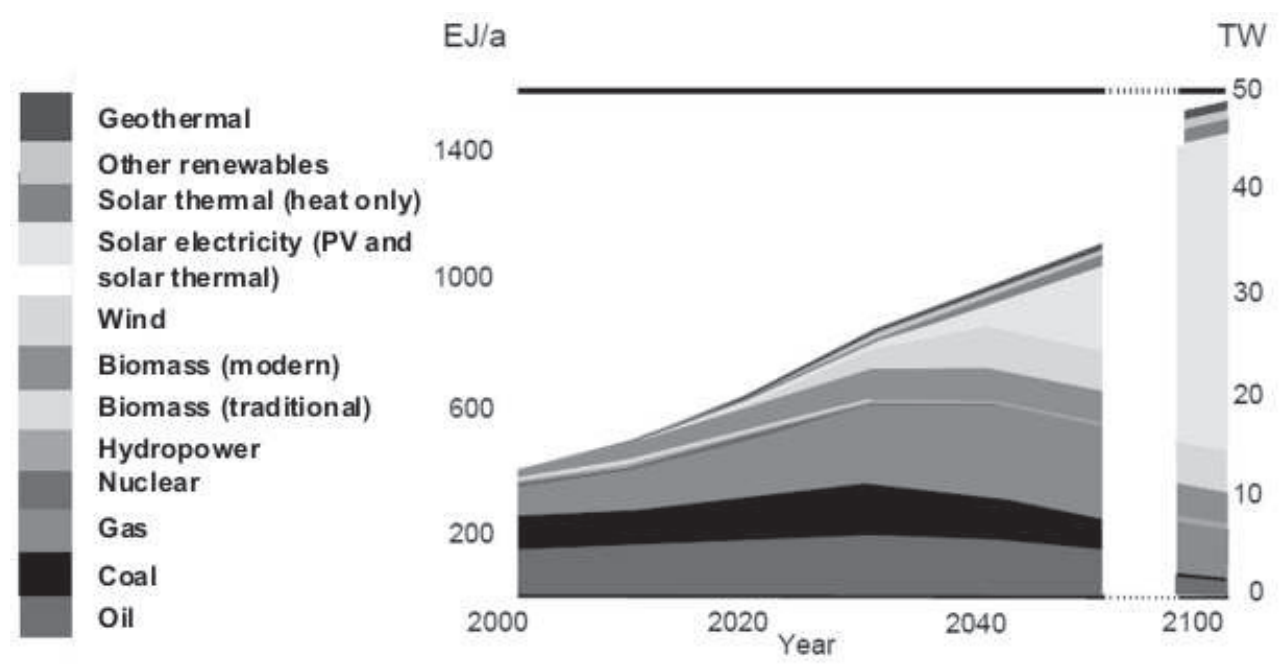

Figure 2: Projected global primary energy consumption

(Source: Weber, 2009) 


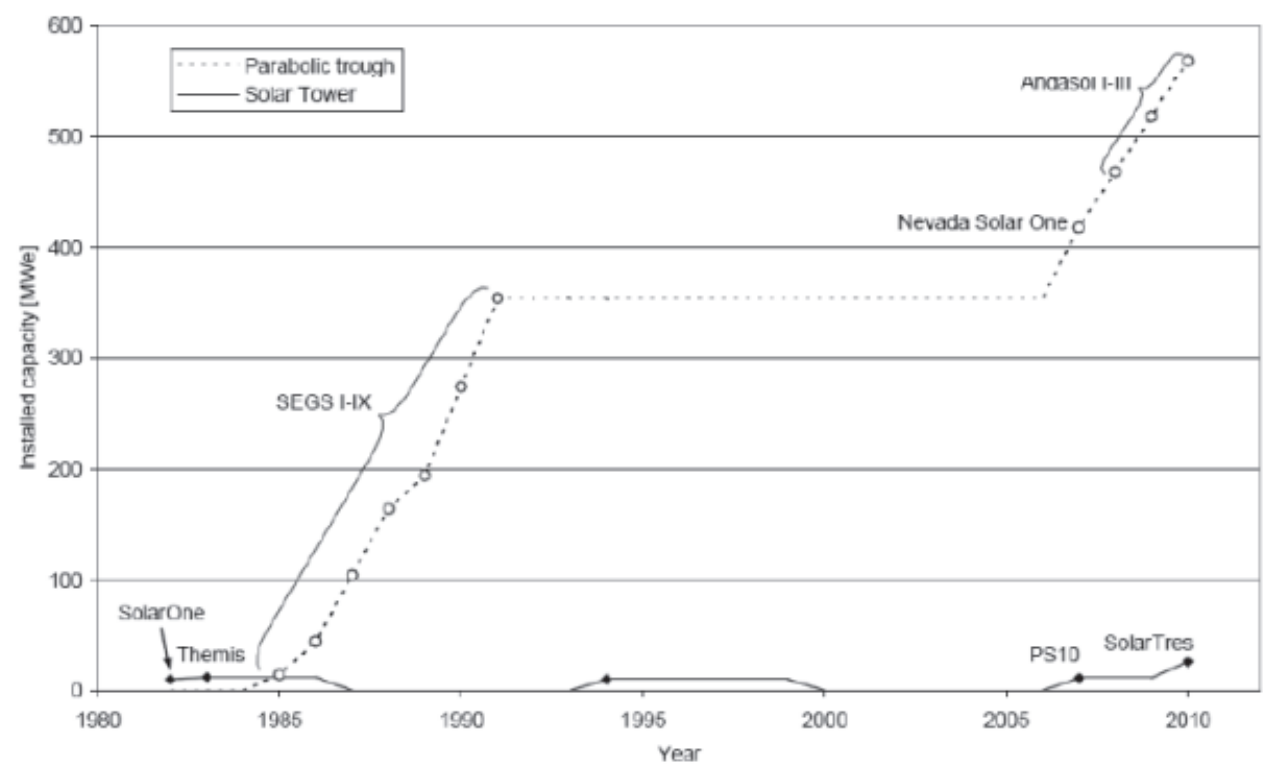

Figure 3: Development and implementation of the CSP technology

(Source: Fluri et al., 2008)

two more $50 \mathrm{MW}$ plants and $20 \mathrm{MW}$ of CSP integrated with a $450 \mathrm{MW}$ natural-gas combined-cycle plant in Morocco; this is the first operational plant of this type.

The pipeline of projects under development or construction increased dramatically during 2008, to more than $8 \mathrm{GW}$ by some estimates, with over 6 GW under development in the United States alone. New projects are under contract in Arizona, California, Florida, Nevada, and New Mexico in the United States and under development in Abu Dhabi, Algeria, Egypt, Israel, Italy, Portugal, Spain, and Morocco. A growing number of these future CSP plants will include thermal storage to allow operation into the evening hours. For example, the Andasol-1 plant in Spain has more than seven hours of full-load thermal storage capability, and a 280 MW plant is planned in Arizona with six hours storage (REN21, 2009).

The CSP industry saw many new entrants in terms of manufacturing facilities in 2008. Active project developers grew to include Ausra, Bright Source Energy, eSolar, FPL Energy, Infinia, Sopergy, and Stirling Energy Systems in the United States; Abengoa Solar, Acciona, Iberdrola Renovables, and Sener in Spain; and Solar Millennium in Germany. Ausra also opened a manufacturing facility in the US state of Nevada that began to produce $700 \mathrm{MW}$ per year of CSP components by mid-2009. Schott Solar of Germany opened a manufacturing plant in Spain and is constructing a similar plant in New Mexico to produce receiver tubes. Rio Glass Solar opened a manufacturing plant in Spain for trough mirrors, and Flabeg of Germany announced plans to build a parabolic mirror factory in the United States (REN21, 2009).
These industry trends support the envisaged market developments; expected to reach $20 \mathrm{GW}_{\mathrm{P}}$ by 2020 and $160 \mathrm{GW}_{\mathrm{P}}$ by 2030 (see Figure 4).

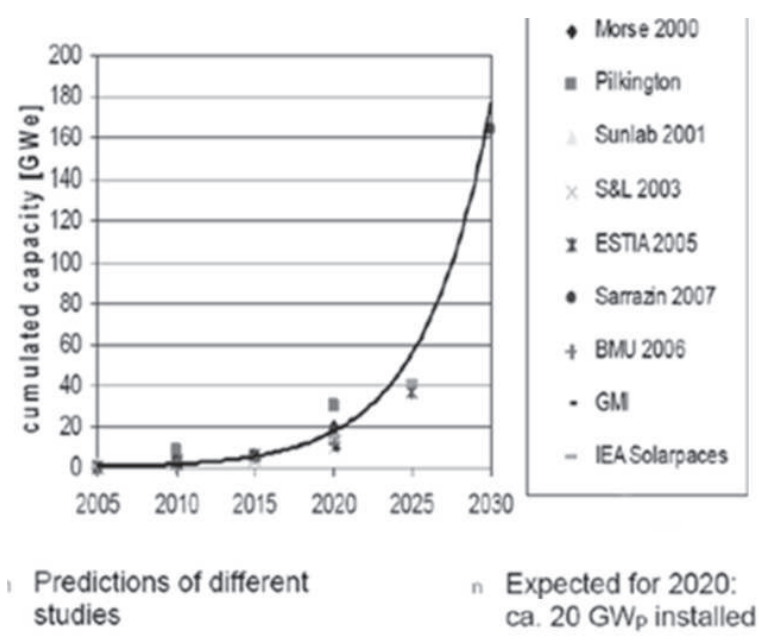

Figure 4. Expected CSP market development (Source: Meyer, 2010)

\subsection{CSP systems - Drivers}

Feed-in-tariffs that are directed towards CSP technologies specifically have been major drivers for these systems (WWG and MMA, 2008). The drive behind the feed-in-tariffs has been the perception that the installation of CSP systems would: meet rapidly growing electricity demand by providing the highest capacity during utility peak loads, namely diversifying energy supply; reduce the load on long distance transmission lines; meet national and regional renewable energy portfolio standards; reduce the demand for and price pressure on non-renewable energy resources; improve and/or maintain air 


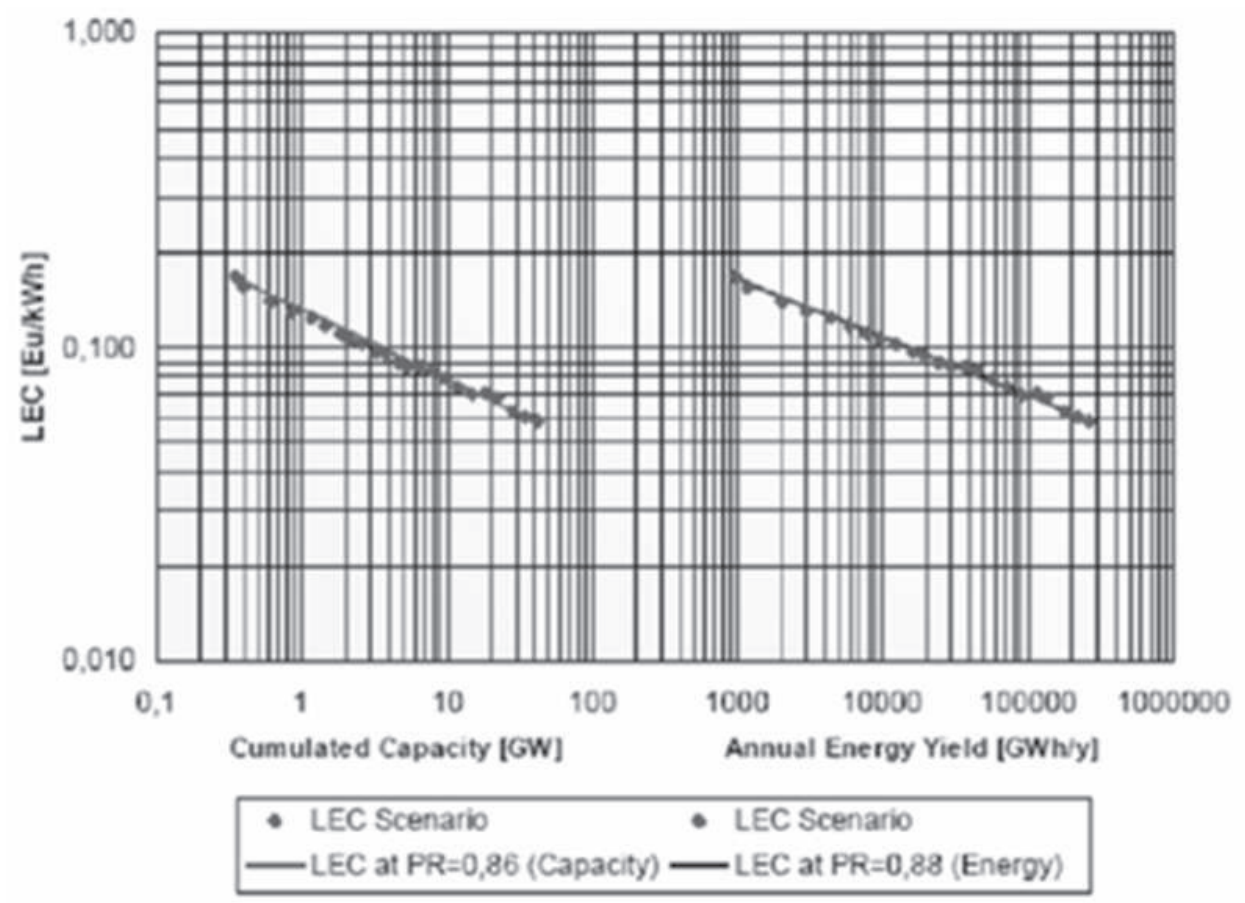

Figure 5: Scenario of reducing levelised electricity cost (LEC) for high temperature solar thermal (HTST) electricity using the learning curve approach

(Source: WWG and MMA, 2008)

quality; and create new jobs and economic opportunity. Furthermore, although CSP systems, in general, cost more today than other renewable options such as wind, there are several risk-related reasons for large-scale utilities to show interest in these systems (WWG and MMA, 2008). For example:

- Thermal storage, or the hybridization of CSP systems with natural gas, avoids the problems of solar intermittency and allows the plant to dispatch power to the line when it is needed.

- The appropriate placement of CSP plants can reduce grid congestion and increase grid reliability.

- Large centrally-located power plants are the

Table 2: Characteristics of CSP systems

(Source: WWG and MMA, 2008)

\begin{tabular}{|c|c|c|c|}
\hline & Parabolic trough & Central receivers & Dish Stirling \\
\hline$\overline{\text { Size }}$ & $30-320 \mathrm{MW}^{*}$ & $10-200 \mathrm{MW}^{*}$ & $5-25 \mathrm{~kW}^{*}$ \\
\hline Operating temperature & $390^{\circ} \mathrm{C}$ & $565^{\circ} \mathrm{C}$ & $750^{\circ} \mathrm{C}$ \\
\hline Annual capacity factor** & $23-50 \% *$ & $20-77 \% *$ & $25 \%$ \\
\hline Peak efficiency & $20 \%(d)$ & $23 \%(p)$ & $29.4 \%(d)$ \\
\hline Net annual efficiency & $11\left(d^{\prime}\right)-16 \% *$ & 7 (d') $20 \% *$ & $12-25(\mathrm{p}) \% *$ \\
\hline Commercial status & $\begin{array}{l}\text { Commercially } \\
\text { available }\end{array}$ & $\begin{array}{c}\text { Scale-up } \\
\text { demonstration }\end{array}$ & $\begin{array}{c}\text { Prototype } \\
\text { demonstration }\end{array}$ \\
\hline Tech. development risk & Low & Medium & High \\
\hline Storage available & Limited & Yes & Battery \\
\hline Hybrid designs & Yes & Yes & Yes \\
\hline \multicolumn{4}{|l|}{ Cost: } \\
\hline$\$ / \mathrm{m}^{2}$ & $630-275^{*}$ & $475-200 *$ & $3100-320 *$ \\
\hline \$/W & $4.0-2.7^{*}$ & $4.4-2.5^{*}$ & $12.6-1.3^{*}$ \\
\hline$\$ / W p^{* * *}$ & $4.0-1.3^{*}$ & $2.4-0.9^{*}$ & $12.6-1.1^{*}$ \\
\hline \multicolumn{4}{|c|}{ Values indicate changes over the 1997 to 2030 timeframe. } \\
\hline \multicolumn{4}{|c|}{ Increases in capacity factor due to the use of thermal storage. } \\
\hline \multicolumn{4}{|c|}{$\begin{array}{l}\text { Removes the effect of thermal storage (or hybridization for Dish Stirling). } \\
(\mathrm{p})=\text { predicted; }(\mathrm{d})=\text { demonstrated; }\left(\mathrm{d}^{\prime}\right)=\text { has been demonstrated - years are predicted values. }\end{array}$} \\
\hline
\end{tabular}




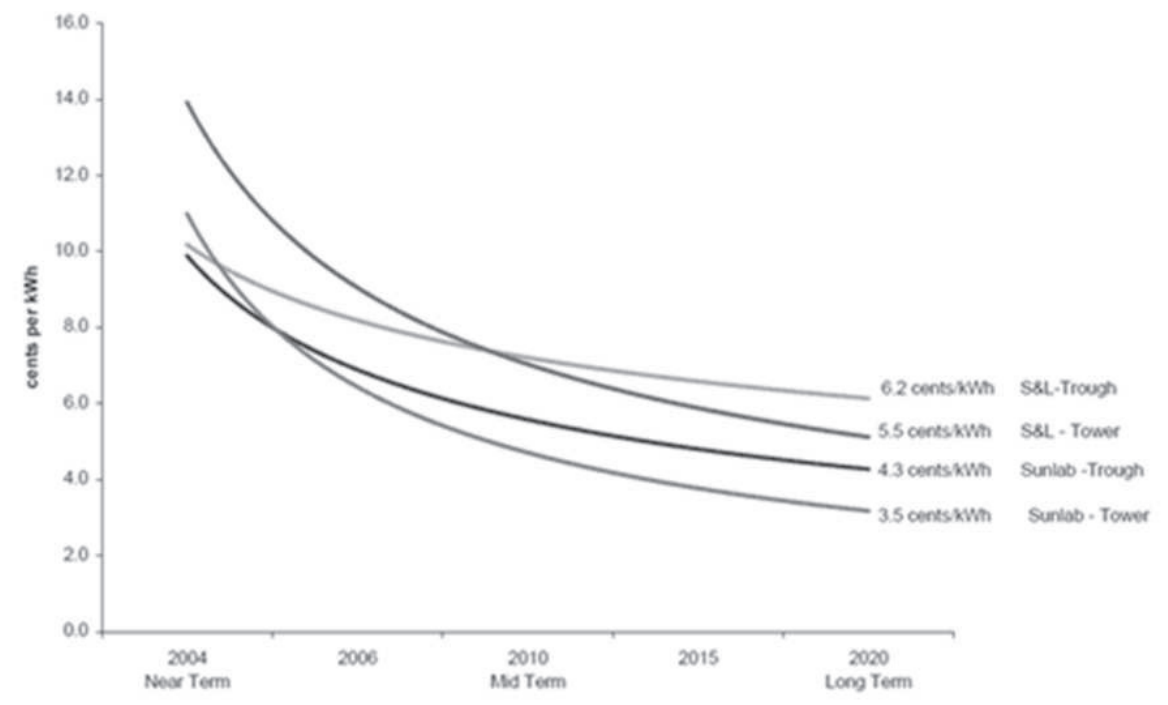

Figure 6: Levelised electricity cost (LEC) predictions for parabolic troughs and central receivers (US cents/kWh)

(Source: Sargent and Lundy Consulting Group, 2003)

types of systems that the utilities have operated for years and with which they are most comfortable.

- Once the CSP plant is built, its energy costs are fixed; this stands in contrast to fossil-fuelled plants that have experienced large fluctuations in fuel prices over the last several years.

Nevertheless, the learning curve of CSP systems seems to have a smaller slope compared to, for example, photovoltaic systems (see Figure 5), and the industry drive is for cost reductions through plant scale-up $(20 \% / 48 \%)$, volume production $(26 \% / 28 \%)$ and technological advancement (54\%/24\%) (see Table 2, Figure 6, and Table 3).

Table 3: Installed and predicted capacities for CSP technologies (MWe)

(Source: Fluri et al., 2008)

\begin{tabular}{lcc}
\hline CSP system & Installed (2008) & Predicted (2018) \\
\hline Parabolic trough & 418 & 3528 \\
\hline Central receivers & 11 & 1353 \\
\hline Linear Fresnel & 0 & 477 \\
\hline Dish Stirling & $<2$ & 800 \\
\hline
\end{tabular}

The typical cost breakdown of a CSP system is shown in Figures 7 and 8. Much of the current R\&D effort is due to a market push from the material manufacturing sectors, as well as a market pull from the CSP manufacturing sector for system components. It is at this interface that significant cost reductions are expected to optimise the CSP value chain.

\subsection{Trends and drivers for thermal applications}

The European Solar Thermal Industry Federation has found that (EUREC, 2009):

- In OECD countries, industry accounts for $30 \%$ of energy consumption;

- In the EU, two-thirds of this $30 \%$ consists of heat rather than electrical energy; and

- About $50 \%$ of the industrial heat demand lies below $250^{\circ} \mathrm{C}$, a large proportion of which can be supplied by current or close-to-market solar thermal technologies.

Other studies have had similar findings (Weiss et al., 2009) and the industrial heat demand has been described in temperature ranges:

- Below $400^{\circ} \mathrm{C}$ : $57 \%$;

- Below $250^{\circ} \mathrm{C}$ (in several industrial sectors): $60 \%$; and

- Below $100^{\circ} \mathrm{C}: 30 \%$ of the total figure.

Figure 9 and Table 4 show the industrial heat demand share broken down by temperature level and industrial sector for thirty-two European countries: EU25 plus Bulgaria, Romania, Turkey, Croatia, Iceland, Norway and Switzerland.

In Europe, the key sectors are food (including wine and beverage), textile, transport equipment, metal and plastic treatment, and chemical. The areas of application with the most suitable industrial processes include cleaning, drying, evaporation and distillation, blanching, pasteurisation, sterilisation, cooking, melting, painting, and surface treatment. Space heating and cooling of factory buildings are also included among the most promising applications. In these sectors, solar thermal heat could be very effective, as the heat demand is more or less continuous throughout the year; and the temperature level required by some of the processes is compatible with the efficient operation of solar thermal collectors.

About ninety operating solar thermal plants for process heat exist worldwide, with a total capacity 


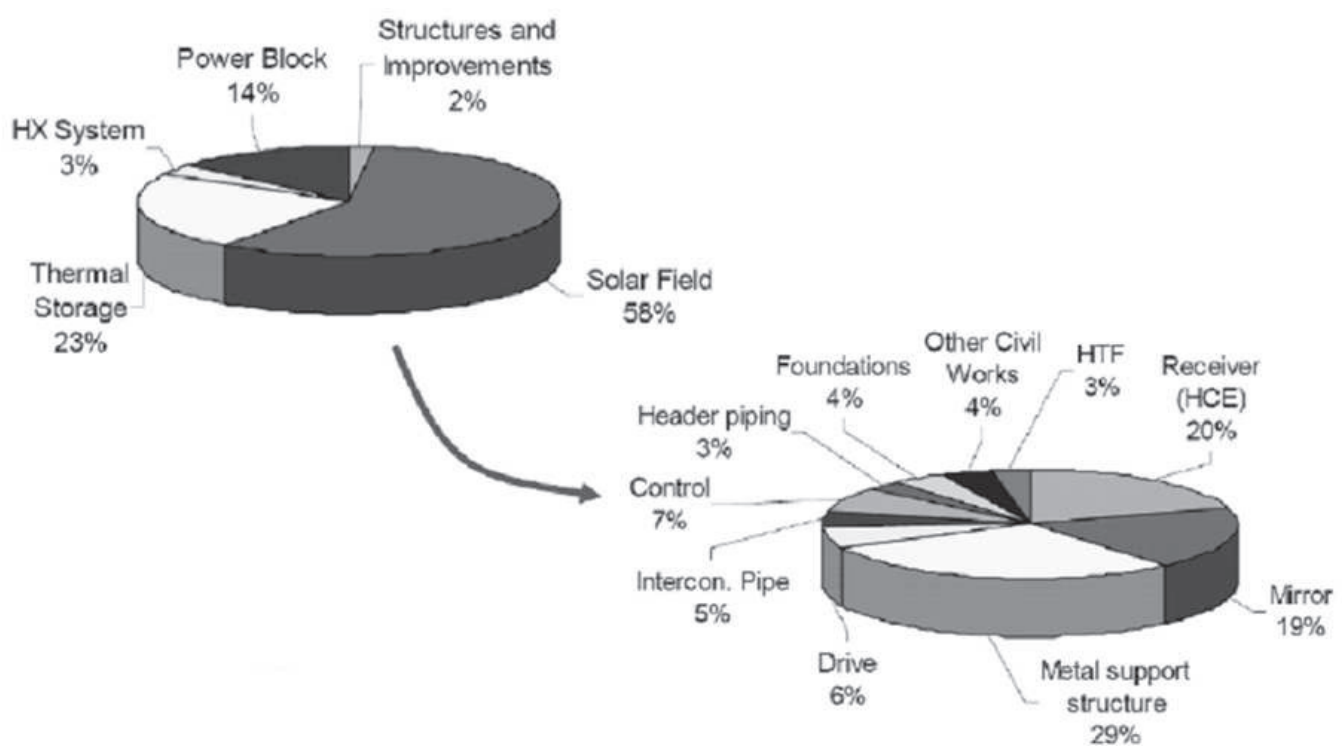

Figure 7: Cost breakdown of a typical CSP system

(Source: Sargent and Lundy Consulting Group, 2003)
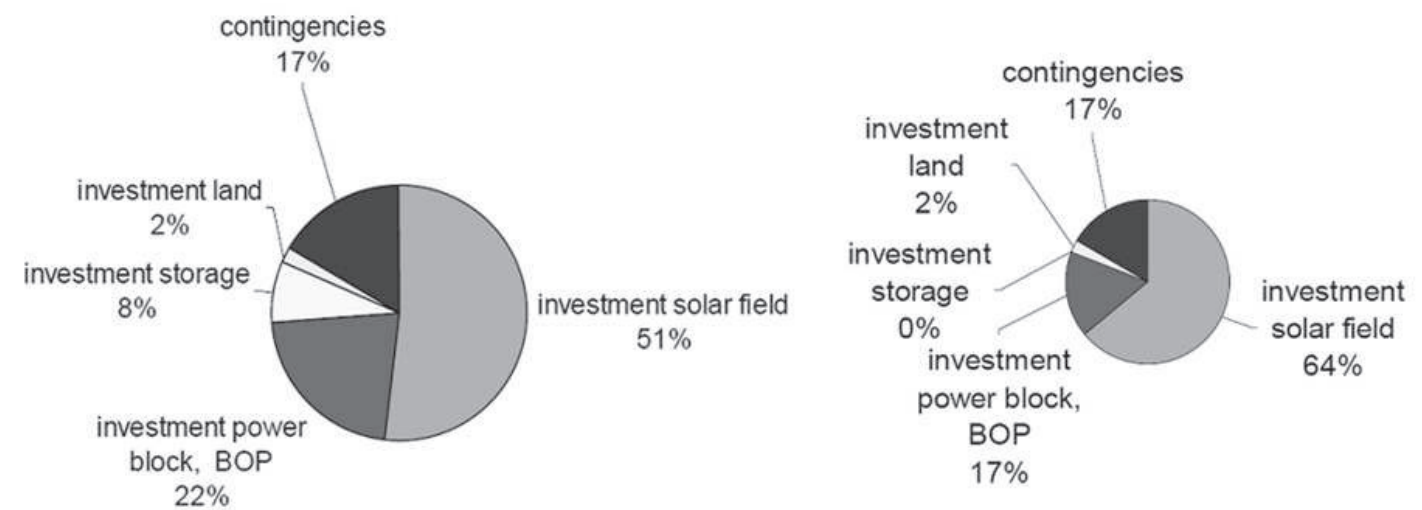

Figure 8: Comparison of investment breakdown of two 50MW parabolic trough plants: thermal oil with three hours storage (left), direct steam generation with no storage (right)

(Source: Pitz-Paal et al., 2005)

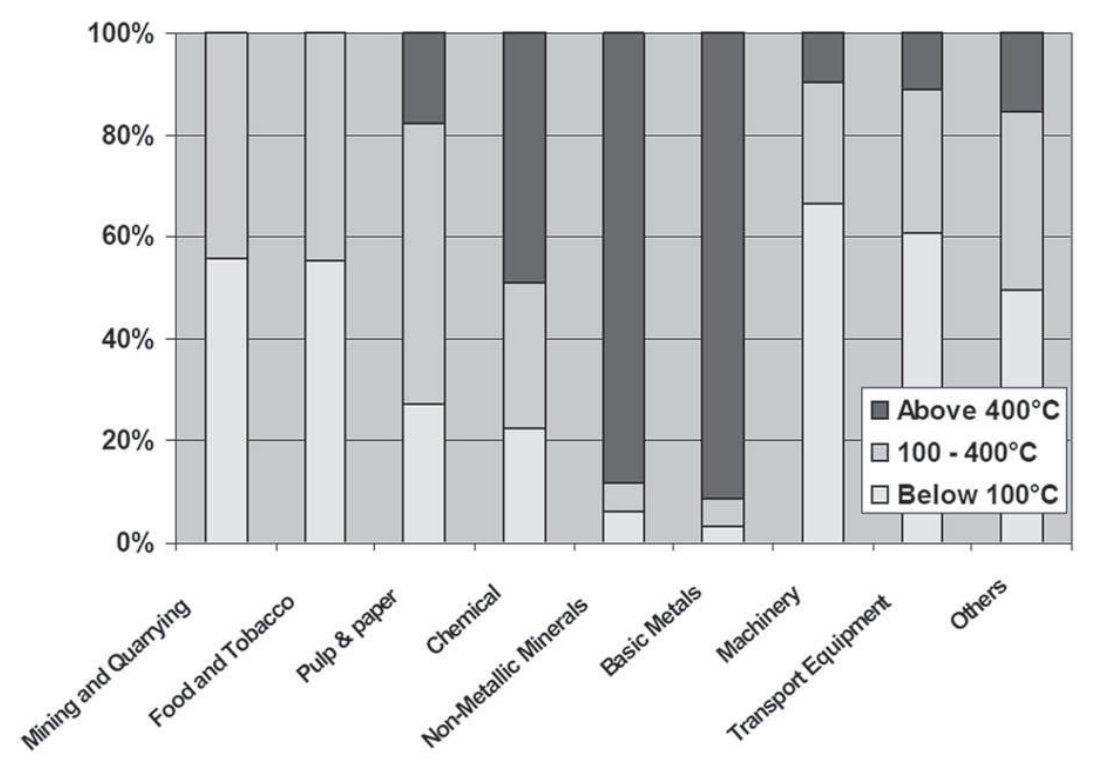

Figure 9: Share of industrial heat demand by temperature level and industrial sector (Source: Vannoni et al., 2008) 
Table 4: Industrial heat demand and solar process heat potential for selected countries and for EU25

(Source: Vannoni et al, 2008)

\begin{tabular}{lcccc}
\hline Country & Industrial heat demand & $\begin{array}{c}\text { Solar process heat } \\
\text { potential: low and } \\
\text { medium temperature } \\
\text { PJ/year }\end{array}$ & $\begin{array}{c}\text { Solar process heat/ } \\
\text { Ind. heat demand }\end{array}$ & $\begin{array}{c}\text { Potential in terms } \\
\text { of capacity }\end{array}$ \\
\hline Austria & 137 & 5.4 & 3.9 & GWth \\
\hline Spain & $493^{*}$ & 17.0 & 3.4 & $3.5-7$ \\
\hline Portugal & $90^{*}$ & 4.0 & 4.4 & $1.3-1.7$ \\
\hline Italy & 857 & 31.8 & 3.7 & 10 \\
\hline Netherlands & 46 & 1.95 & 3.2 & $0.5-0.7$ \\
\hline EU 25 & 6,881 & 258.2 & 3.8 & $100-125$ \\
\hline
\end{tabular}

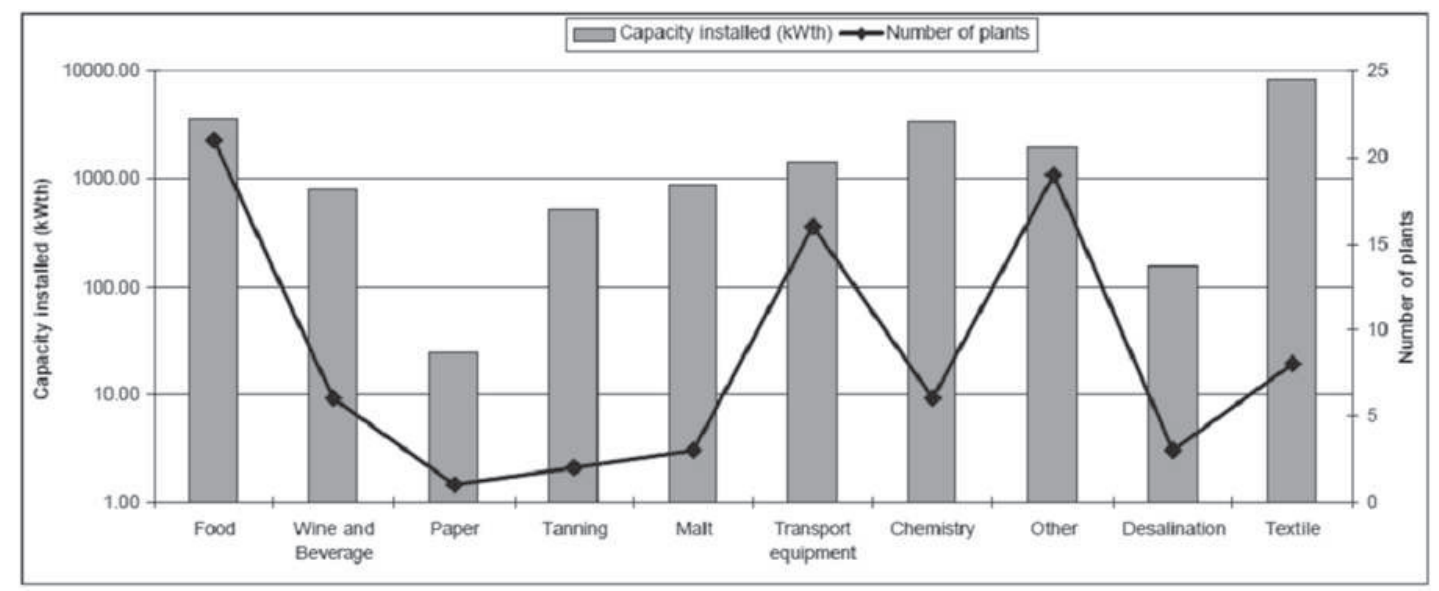

Figure 10: Solar industrial process heat plants - distribution by industry sector

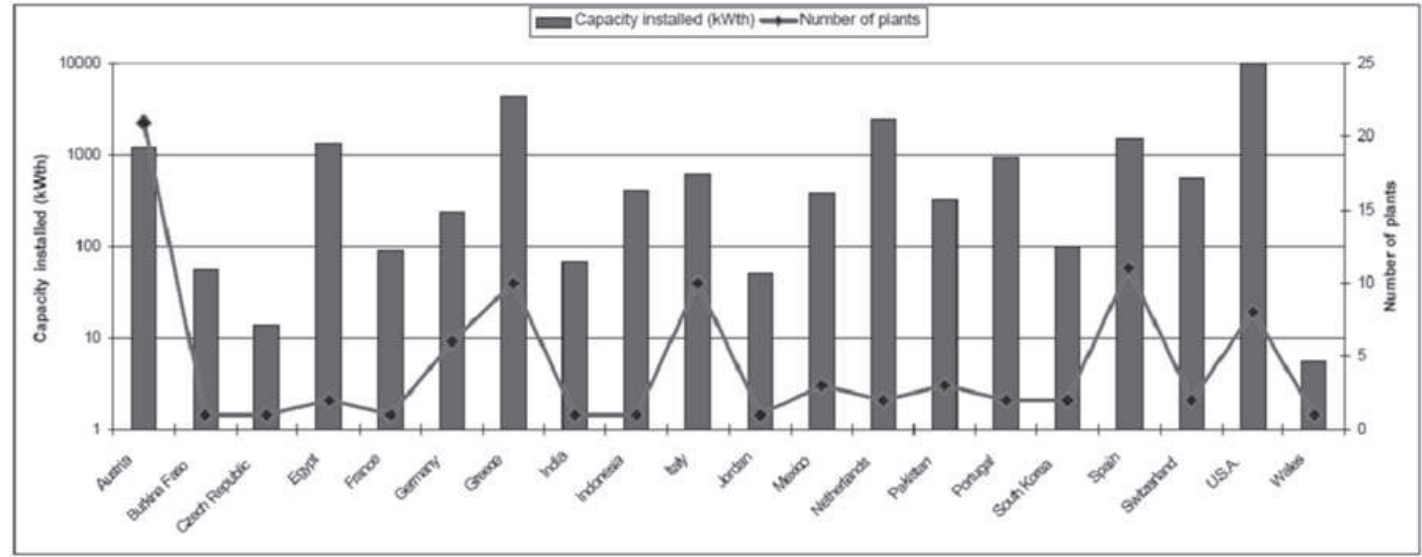

Figure 11: Solar industrial process heat plants - distribution by country

(Source: Vannoni et al., 2008)

of about $25 \mathrm{MW}_{\text {th }}\left(35000 \mathrm{~m}^{2}\right)$. This is a very small fraction $(0.02 \%)$ of the total solar thermal capacity installed worldwide, which equals $118 \mathrm{GW}_{\text {th }}$ (mostly domestic solar water heating, pool heating and space heating). Figures 10 and 11 show the distribution of capacity by industry and country respectively. The low figure of $0.02 \%$ of the installed solar thermal capacity for industrial process heat, com- pared to existing domestic water heating, shows a great opportunity for improvement.

\subsubsection{High temperature applications}

The trends in high temperature, concentrating thermal with tracking applications have largely been through combined heat and power (CHP) systems that are located at industrial and very large com- 
mercial facilities; these systems generate both power and steam. The steam is used on site (or nearby) for process heat or space conditioning, and the power may be used on site or sold to the grid (EAC, 2009). These plants can have very high efficiency $(45 \%$ to $80 \%)$ because much of the heat is used and not wasted. In 2006, CHP systems generated about 322 TWh of electricity in the United States, accounting for $7.9 \%$ of net generation that year (EAC, 2009). Several studies have estimated that the amount of power from CHP could be increased by more than $50 \%$ (Shipley et al., 2009). However, little information is available in terms of non-renewable resource usage, for process heat, which can be replaced over time, but projections are large quantities (Roos, 2009). Nevertheless, realizing this potential will require the overcoming of a variety of barriers, ranging from host-site reluctance to get into the power business, fluctuations in non-renewable fuel and electricity prices over time, and problems with environmental regulations and interconnection requirements in some service areas and jurisdictions (EAC, 2009). The future trends and drivers, and cost implications, are subsequently vague.

A number of solar thermochemical processes are being investigated; most notably the production of hydrogen as a clean liquid fuel (see Figure 12). Economic assessments (Steinfeld, 2005) have indicated that the solar thermochemical production of hydrogen can be competitive with the electrolysis of water using solar-generated electricity, and, under certain conditions, might become competitive with conventional fossil-fuel-based processes at the then
(2005) fuel prices, even before the application of credit for $\mathrm{CO}_{2}$ mitigation and pollution avoidance. However, there are (still) many uncertainties associated with the viable efficiencies and investment costs of the various components due to their early stage of development and their economy of scale. Thus, further developments and large-scale demonstrations are warranted (Steinfeld, 2005). Also, the market projections of a hydrogen economy are still much debated (NAE, 2004) and it is difficult at this stage to ascertain the market pull that will drive down the costs of these technological systems.

\section{South African market potential and barriers to be addressed through research and development}

A 'progressive renewable scenario' for South Africa has shown the largest shift to be in the electricity supply sector. To meet electricity demands, the current models project that within the next two decades active solar systems could contribute as much to the power mix as wind energy. Thermal applications are mostly modelled as demand side energy efficiency measures, but Banks and Shäffler (2006) have predicted a steady, but small, growth in the solar water heating, which includes process heat, as energy supply markets. Nevertheless, South Africa has seen recent market developments that will drive the implementation of active solar energy systems, even within a number of constraints that have been identified primarily pertaining to governance issues (Sebitosi and Pillay, 2008). For example, the evidence of uncoordinated and at times conflicting approaches by various arms of government.

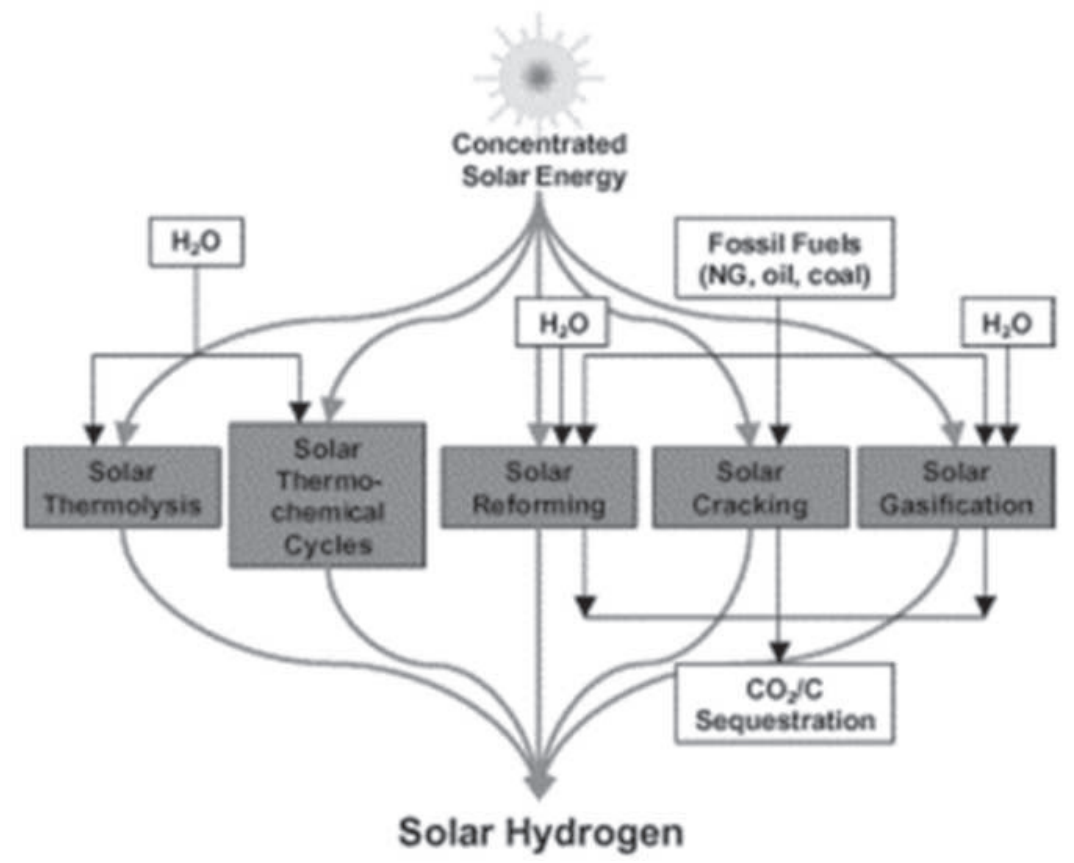

Figure 12: Five thermochemical routes for the production of solar hydrogen (Source: Steinfeld, 2005) 


\subsection{CSP systems - Market potential}

The contribution of concentrating solar power (CSP) systems to the South African market is not limited by general resource availability. Furthermore, the materials used to construct CSP plants are (mostly) readily available and land use is not a significant constraint. Given that thermal storage is an option in CSP systems, they can also more readily match the supply/demand needs of the national grid (Banks and Shäffler, 2006). It is for these reasons that the renewable energy feed-in-tariff (REFIT) scheme places much emphasis on CSP systems (NERSA, 2009). Thereby the government aims to create a sufficient market that may drive the CSP industry towards greater commercialisation and eventually drive the price of electricity from CSP systems low enough to make them competitive with conventional generation sources (Edkins et al., 2009).

CSP learning curves are thought to be anywhere in the range of 5 to $32 \%$, for parabolic trough systems, and 2 to $20 \%$, for central receiver systems (Winkler et al., 2007; 2009). As the technology matures on a global scale, cost reductions are thought to come from production changes (process innovations, learning effects and scaling effects), product changes (innovation, design standards and redesign) and changes in input prices (Edkins et al., 2009). Models (Marquard et al., 2008) have subsequently indicated that the levelised electricity cost (LEC) from CSP systems may be competitive with the conventional coal systems by 2045 and with nuclear by 2026 (see Figure 13). However, the uncertainties of the costs are still high with estimates currently between $\mathrm{R} 1 / \mathrm{kWh}$ and $\mathrm{R} 2 / \mathrm{kWh}$, although predictions are that the costs should come down to below R0.60/kWh within the next four years (Fluri et al., 2008).
In the long-term, post-2030, the large-scale rollout of CSP is expected to achieve cost savings for the South African electricity generation sector (Edkins et al., 2009). Until then, however, the additional cost to the electricity system is estimate at R2.5 billion for 2010 to 2015 , R8 billion for 2016 to 2020 and R23 billion for 2021 to 2030 (see Table $5)$.

The models of the long-term mitigation scenarios (SBT, 2007), which incorporate technology learning rates for CSP systems, indicate that the incremental investment costs to achieve the rollout of CSP systems on the scale envisioned for the scenarios would be R3.9 billion per year for the 'Start' (2010 to 2015) period; rising to R4.4-4.9 billion per year for the 'Scale Up' (2016 to 2030) period; and further rising to about R13 billion per year for the 'Rollout' (2031 to 2050) period (Edkins et al., 2009; Winkler et al., 2009; Haw and Hughes, 2007). How potential changes in the REFIT may affect the annual incremental cost thereof have also been calculated (see Figure 14). With a reduction in the tariff by $15 \%$ per year, in line with the estimated learning rate of CSP systems, from 2014 onwards, after the first CSP plants have been constructed, the annual cost of REFIT would peak around R30 billion in 2020. However, CSP technologies may experience higher technology learning rates if a local CSP component supply industry is developed (Edkins et al., 2009). This would result in reduced upfront investment costs for CSP plant constructions, which, in turn, may reduce the LEC (see Figure 13). If investment cost reductions of $5 \%$ per year can be achieved due to local production, in addition to global technology learning for CSP systems, then incremental investment costs for the large-scale rollout of CSP is estimated (Edkins et al., 2009) to be much lower (see Table 5).

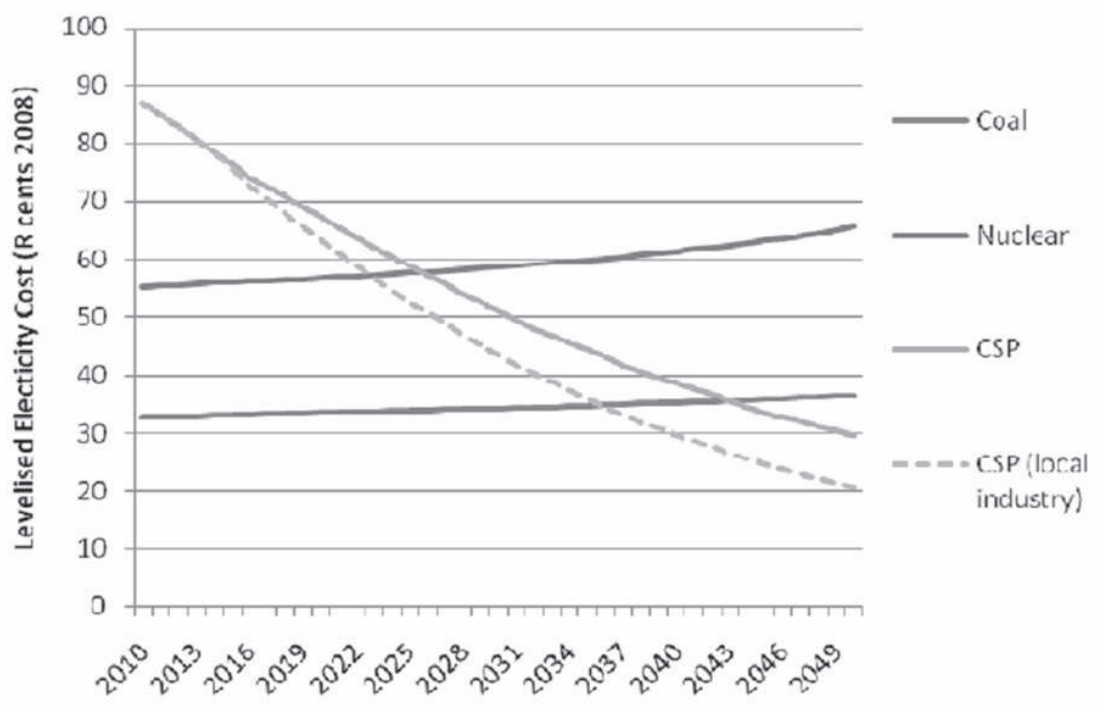

Figure 13: Projections of the LECs from coal, nuclear and CSP systems in South Africa (Source: Marquard et al., 2008) 
Table 5: Scenarios for large-scale rollout of CSP in South Africa (Source: Edkins et al., 2009)

\begin{tabular}{|c|c|c|c|c|}
\hline & \multirow{2}{*}{$\begin{array}{c}\text { Start } \\
2010-2015\end{array}$} & \multicolumn{2}{|c|}{ Scale-up } & \multirow{2}{*}{$\begin{array}{c}\text { Rollout } \\
2031-2050\end{array}$} \\
\hline & & $2016-2020$ & $2021-2030$ & \\
\hline $\mathrm{CO}_{2}$-eq emissions avoided & $\begin{array}{c}20 \mathrm{Mt} \\
(4 \mathrm{Mt} / \mathrm{yr})\end{array}$ & $\begin{array}{c}140 \mathrm{Mt} \\
(28 \mathrm{Mt} / \mathrm{yr})\end{array}$ & $\begin{array}{c}370 \mathrm{Mt} \\
(38 \mathrm{Mt} / \mathrm{yr})\end{array}$ & $\begin{array}{c}3270 \mathrm{Mt} \\
(165 \mathrm{Mt} / \mathrm{yr})\end{array}$ \\
\hline $\begin{array}{l}\text { Share of electricity sector } \\
\text { (installed generating capacity) }\end{array}$ & $\begin{array}{c}4 \% \\
(2 \mathrm{GW}) \text { by } 2015\end{array}$ & $\begin{array}{c}13 \% \\
(7 \mathrm{GW}) \text { by } 2020\end{array}$ & $\begin{array}{c}27 \% \\
(24 \mathrm{GW}) \text { by } 2030\end{array}$ & $\begin{array}{c}55 \% \\
(100 \mathrm{GW}) \text { by } 2050\end{array}$ \\
\hline $\begin{array}{l}\text { Incremental cost to electricity } \\
\text { generation system }^{\mathrm{a}}\end{array}$ & $\begin{array}{c}2.5 \\
(0.4 / \mathrm{yr})\end{array}$ & $\begin{array}{c}8 \\
(1.6 / \mathrm{yr})\end{array}$ & $\begin{array}{c}23 \\
(2.3 / y r)\end{array}$ & $\begin{array}{c}-2 \\
(-0.1 \cdot y r)\end{array}$ \\
\hline $\begin{array}{l}\text { Incremental investment cost of } \\
\text { - with technology learning }\end{array}$ & $\begin{array}{c}\text { CSP rollout }^{a} \\
23.5 \\
(3.9 / y r) \\
\end{array}$ & $\begin{array}{c}24.6 \\
(4.9 / \mathrm{yr}) \\
\end{array}$ & $\begin{array}{c}44 \\
(4.4 / y r) \\
\end{array}$ & $\begin{array}{c}266 \\
(13 / \mathrm{yr})\end{array}$ \\
\hline $\begin{array}{l}\text { - with technology learning } \\
\text { and local production }\end{array}$ & $\begin{array}{c}22.9 \\
(3.8 / y r)\end{array}$ & $\begin{array}{c}19.4 \\
(3.9 / \mathrm{yr})\end{array}$ & $\begin{array}{c}20 \\
(2 / y r)\end{array}$ & $\begin{array}{c}87 \\
(4.3 / y r)\end{array}$ \\
\hline
\end{tabular}

\section{Notes:}

a) Billion rands in 2008 .

b) Learning ratio is $15 \%$ and $20 \%$ reduction per doubling of deployment for parabolic trough and central receivers respectively.

c) Local production of CSP components is assumed to reduce CSP investment costs at a rate of $5 \%$ per year.

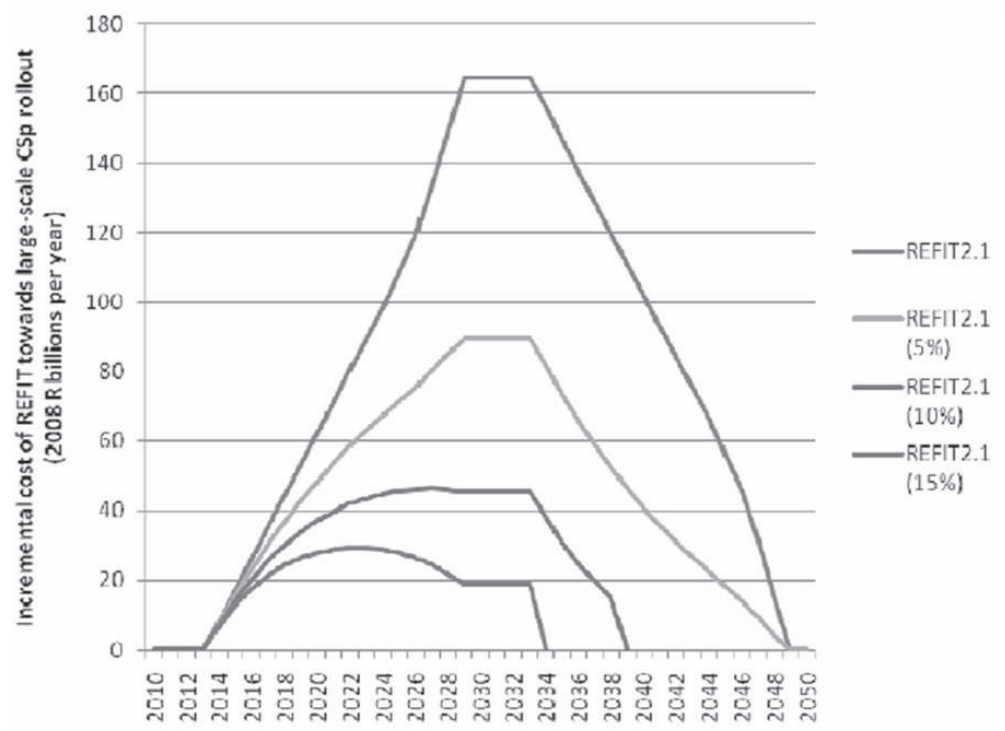

Figure 14: Estimated annual costs of REFIT, reduced by $5 \%, 10 \%$ and $15 \%$ after the first CSP plants are built in 2014, in support of the large-scale rollout of CSP

(Source: Edkins et al., 2009)

\subsection{CSP systems - Market barriers}

A workshop facilitated by the Energy Research Centre (ERC) highlighted that a solar industry development programme could lead to large-scale employment creation and possible foreign earnings through the export of the technology, especially if South Africa were to become a market leader in the less developed central receiver and linear Fresnel technologies (Edkins et al., 2009). It was further noted that the well-established automotive manufacturing industry could possibly evolve to supply the CSP industry. If 5.9 employment opportunities are expected for each MW of CSP generation capacity constructed then the large-scale rollout of
CSP may result in creating over 600000 employed positions. However, the same workshop raised a number of issues facing the large-scale rollout of CSP in South Africa. The largest barrier is financial support, with the others grouped into technological (innovate), infrastructure (operate), industry-related (manufacture) and legal/regulatory (regulate) issues (see Table 6).

Some of these barriers can be addressed by concerted research efforts. For example:

- To start large-scale rollout of CSP, South Africa would have to invest in importing the required technology, in particular parabolic trough technologies: Technology transfer issues and chal- 
Table 6: Main barriers facing the large-scale rollout of CSP in South Africa

(Source: Adapted from Edkins et al., 2009)

\begin{tabular}{|c|c|c|c|}
\hline & $\begin{array}{l}\text { Start } \\
2010-2015\end{array}$ & $\begin{array}{l}\text { Scale-up } \\
2016-2020\end{array}$ & $\begin{array}{l}\text { Rollout } \\
2021-2050\end{array}$ \\
\hline Innovate & $\begin{array}{l}\text { Import technology } \\
\text { Thermal storage technology } \\
\text { Eskom cooperation }\end{array}$ & $\begin{array}{l}\text { South African specific } \\
\text { technology }\end{array}$ & Water-saving technology \\
\hline $\begin{array}{l}\text { Adopt / } \\
\text { manufacture }\end{array}$ & $\begin{array}{l}\text { Risky investment: 'Test Plant' } \\
\text { branding - no market outlook }\end{array}$ & Lacking skills for local content & \\
\hline $\begin{array}{l}\text { Operate / } \\
\text { maintain }\end{array}$ & Initial grid expansion & $\begin{array}{l}\text { Massive grid expansion } \\
\text { Lacking skills }\end{array}$ & $\begin{array}{l}\text { Grid-wide storage } \\
\text { Water-stress }\end{array}$ \\
\hline Regulate & REFIT untested & REFIT expiry unknown & SAPP day-ahead market \\
\hline Finance & $\begin{array}{l}\text { Venture capital and grants from } \\
\text { climate change funds, e.g. } \\
\text { World Bank and other Clean } \\
\text { Technology Funds }\end{array}$ & $\begin{array}{l}\text { Investment facilitation; } \\
\text { NAMA crediting from climate } \\
\text { change funds and loans }\end{array}$ & $\begin{array}{l}\text { Equity, mezzanine, debt, } \\
\text { insurance and carbon-based }\end{array}$ \\
\hline $\begin{array}{l}\text { Stakeholder } \\
\text { interests }\end{array}$ & REFIT established & $\begin{array}{l}\text { Growing solar industry } \\
\text { development programme }\end{array}$ & $\begin{array}{l}\text { Future employment and } \\
\text { exports }\end{array}$ \\
\hline $\begin{array}{l}\text { Stakeholder } \\
\text { concerns }\end{array}$ & REFIT untested & $\begin{array}{l}\text { Eskom as electricity distributor } \\
\text { Assessments }\end{array}$ & $\begin{array}{l}\text { Environmental Impact } \\
\text { - water }\end{array}$ \\
\hline
\end{tabular}

lenges need to be investigated.

- Thermal storage technology, such as motel salt storage, would also have to be acquired, and importing such technology may prove costly: New storage technologies need to be researched and developed.

- Smaller-scale applications of CSP for off-grid communities or rooftops are required: Feasibility studies and demonstration facilities need to be developed.

- Existing hybrid systems are not appropriate for South Africa, since these systems rely primarily on natural gas: Coal would also have to be investigated for country-specific CSP designs as a suitable backup fuel.

- The availability of water resources: Changes in availability due to climate change needs to be investigated as well as novel water resource management practices; existing dry cooling technology expertise need to be expanded in the country.

- Infrastructure barriers: Integrated planning studies need to be ongoing, and especially pertaining to transmission and storage on the national grid, e.g. through the promotion of electric vehicles or more pump-storage schemes.

- Governance barriers: Regulatory barriers, such as the Environmental Impact Assessment process, need to be investigated, as well as developing the NSI to expand the existing manufacturing sector to accommodate a CSP industry in South Africa.

In all cases financial support for these research efforts are necessary for CSP developers to prepare feasibility studies. For the Start phase of large-scale CSP rollout in South Africa (2010 to 2015) financing could come from commercial investors and development financers, such as the Industrial Development Corporation (Maia, 2009). However, the current global economic climate presents difficulties for CSP developers to access finance, even with the REFIT in place (Edkins et al., 2009), and public financing mechanisms are therefore (still) required. These would include $\mathrm{R} \& \mathrm{D}$ support and grants from climate change funds, such as the Clean Technology Fund of the World Bank (2009), and the Clean Technology Fund Investment Plan of the Government of South Africa (2009).

\subsection{Potential for thermal applications}

High temperature applications of concentrating solar thermal systems have been considered in the South African context, especially within the heavy industrial base of the country to improve energy (and carbon) efficiencies, and for specific applications such as the gasification of coal (Roos, 2009). It has been concluded (Weiss, 2009; EAC, 2009) that solar thermal could provide the European industrial sector with 3 to $4 \%$ of its heat demand (see Figure 9 and Table 4). Given that South Africa has a better solar resource than Europe and the industries described exist in South Africa, the penetration of solar process heat technologies into these industries in South Africa can be expected to be comparable or better with suitable support initiatives.

Now in South Africa, the food, wine and beverage, paper, textile and automotive industries all exist. They can be targeted for solar process heat in the same way as Europe. Unfortunately, though, these sectors form a much smaller fraction of energy demand in South Africa than in Europe. Figures 15 and 16 show that the industrial sector comprises $41 \%$ of energy use, similar to the $30 \%$ of Europe. 

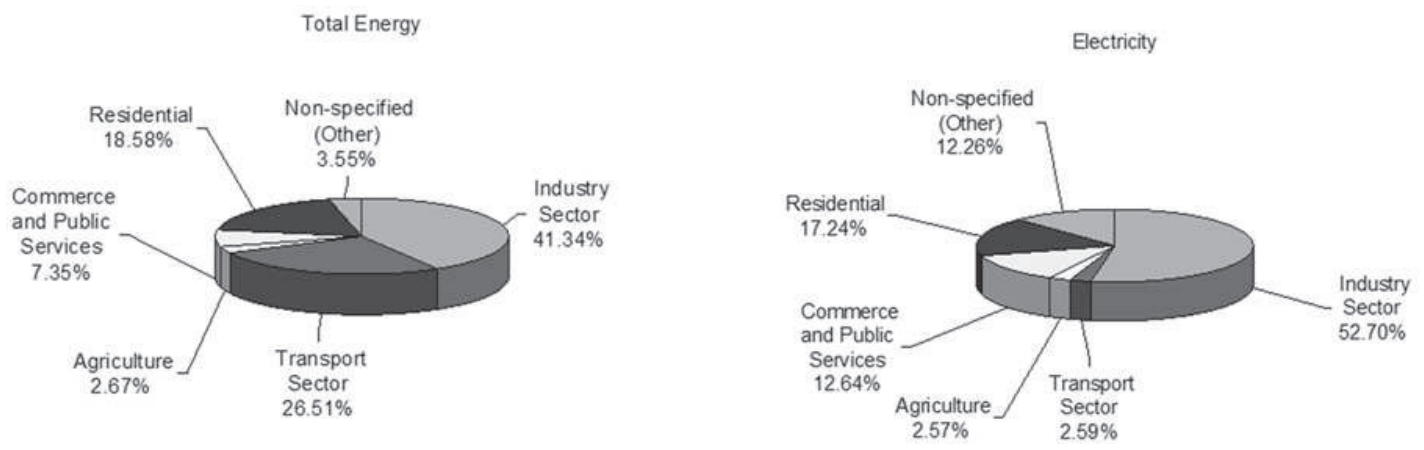

Figure 15: Total energy and electricity consumption in South Africa per sector in 2005 (Source: DME, 2006)
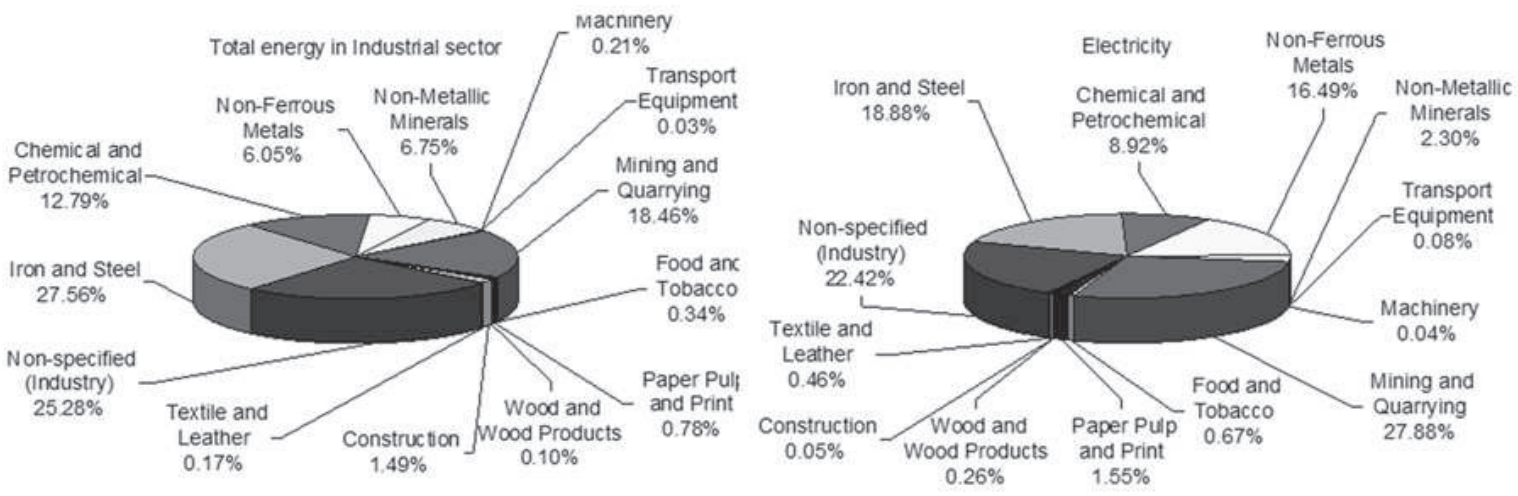

Figure 16: Total energy and electricity consumption in the industrial sector in South Africa per sector in 2005

(Source: DME, 2006)

Within the industrial sector, however, mining, iron and steel, non-ferrous metals and non-metal minerals together consume $59 \%$ of energy and $66 \%$ of electricity consumed in the industrial sector.

Here the greatest contribution that could be made by solar industrial process heat would probably be provided by parabolic troughs: firstly driving double effect absorption chillers for mining ventilation, and secondly providing process steam in the chemical and petrochemical industries, and others. Air conditioning of commercial buildings may require single-effect absorption chillers with stationary collectors as typical roof structures may not be ideal for parabolic troughs. A small linear Fresnel system, which can drive a double effect absorption chiller, would be ideal, however, because of lesser weight and area requirements, especially on flat roofs. The use of solar collectors to drive large-scale thermal desalination plants, such as multi-effect desalination or multi-stage flash evaporation, allows a solution to both mine acid drainage and the provision of fresh water at mines.

Important here is the realisation that the manufacturing and installing of collectors for solar industrial process heat is an industry in its own right, meeting government imperatives of labour-intensive employment, climate change mitigation, and energy security.

\section{Discussion - The way forward}

To develop the solar energy technology roadmap (SETRM) (DST, 2010), strength, weakness, opportunity and threat (SWOT) analyses were conducted for the different applications and technological systems in the South African national system of innovation (NSI). The SWOT analyses were complimented with market readiness analyses of the different technological systems based on current international advances in the technological systems, the international market trends and drivers, and the South African market potential and barriers that may be addressed through research and development $(\mathrm{R} \& \mathrm{D})$. The analyses revealed the $\mathrm{R} \& \mathrm{D}$ requirements of the different technologies, as well as the requirements of those technologies that have been demonstrated, which need to be commercialised in South Africa, and those that are already commercialised and can therefore be acquired directly. The requirements are summarised in Table 7.

Those technological platforms that are in the demonstrated and commercialised life cycle phase (see Table 7) were then further analysed in terms of:

- Government intensity in terms of the requirement for those technological platforms that would stimulate economic growth coupled with industry development and employment cre- 
Table 7: Market readiness in South Africa of the different technological systems

\begin{tabular}{|c|c|c|c|c|}
\hline $\begin{array}{l}\text { Technological } \\
\text { system }\end{array}$ & $\begin{array}{l}R \& D \\
\text { (primarily DST) }\end{array}$ & $\begin{array}{l}\text { Demonstrated } \\
\text { (primarily DoE) }\end{array}$ & $\begin{array}{l}\text { Commercialised } \\
\text { (private sector) }\end{array}$ & $\begin{array}{l}\text { Possible driver } \\
\text { organisations }\end{array}$ \\
\hline \multicolumn{5}{|c|}{ Concentrating solar power } \\
\hline $\begin{array}{l}\text { Parabolic } \\
\text { trough }\end{array}$ & $\begin{array}{l}\text { - Expansion of existing system design, } \\
\text { simulation and optimisation capabilities, } \\
\text { including structure and tracking systems, } \\
\text { and dry cooling for the power block. } \\
\text { - Development of appropriate education } \\
\text { and training programmes. } \\
\text { - Establish R\&D facilities for improved } \\
\text { and new generation absorber and } \\
\text { storage technologies. }\end{array}$ & $\begin{array}{l}\text { - Optimise } \\
\text { receiver system } \\
\text { technologies for } \\
\text { products and } \\
\text { manufacturing }\end{array}$ & $\mathrm{X}$ & $\begin{array}{l}\text { Mining houses } \\
\text { and other } \\
\text { companies } \\
\text { with large } \\
\text { facilities / plants. }\end{array}$ \\
\hline $\begin{array}{l}\text { Central } \\
\text { receivers }\end{array}$ & $\begin{array}{l}\text { - Optimise receiver system technologies for } \\
\text { products and manufacturing. } \\
\text { - Expansion of existing system design, } \\
\text { simulation and optimisation capabilities, } \\
\text { including structure and heliostat systems, } \\
\text { and dry cooling for the power block. } \\
\text { - Development of appropriate education } \\
\text { and training programmes. } \\
\text { - Establish R\&D facilities for improved } \\
\text { and new generation absorber and storage } \\
\text { technologies. }\end{array}$ & $\mathrm{X}$ & & $\begin{array}{l}\text { Eskom, SKA } \\
\text { (Meerkat), } \\
\text { solar parks. }\end{array}$ \\
\hline Linear Fresnel & As with parabolic trough & $\mathrm{X}$ & & $\begin{array}{l}\text { Industrial plants, } \\
\text { commercial } \\
\text { buildings, off- } \\
\text { grid users. }\end{array}$ \\
\hline Dish Stirling & $\mathrm{X}$ & & & $\begin{array}{l}\text { R\&D institutions, } \\
\text { commercial } \\
\text { buildings. }\end{array}$ \\
\hline \multicolumn{5}{|l|}{ Thermal } \\
\hline $\begin{array}{l}\text { Concentrating } \\
\text { with tracking }\end{array}$ & $\begin{array}{l}\text { As with parabolic trough and linear } \\
\text { Fresnel without the power block }\end{array}$ & $\mathrm{X}$ & & $\begin{array}{l}\text { Industrial plants } \\
\text { and agriculture. }\end{array}$ \\
\hline
\end{tabular}

ation, those that would improve energy security and access, and those that would address climate change;

- Industry intensity in terms of those technological platforms that could expand a local supply chain, and lead to a greater export potential of products, technologies and knowledge; and

- R\&D intensity in terms of available capacity and associate resources needed to support the further development of the technological platforms. The analyses are summarised in Figure 17, which guided the SETRM implementation over the next five years, whilst the $R \& D$ requirements and the technology systems in the R\&D life cycle phase of Table 7 guided the SETRM implementation over the next ten years.

\section{Conclusions}

\subsection{The next five years - The short term}

The solar energy technology roadmap (SETRM) highlights six concentred solar thermal technological systems that have clearly been demonstrated or commercialised, where a local industry could be stimulated (with the potential of export opportunities) and the other requirements of government can be met, and that have a medium to high $R \& D$ intensity:

- CSP systems (parabolic trough, linear Fresnel and central receiver) without storage for less than 10 MW grid-connected power supply;

- CSP systems (parabolic trough and central receiver) with storage for more than $50 \mathrm{MW}$ grid-connected power supply;

- Solar heating systems (simple parabolic trough) for process heat of less than $150^{\circ} \mathrm{C}$;

- Solar heating systems (parabolic trough and linear Fresnel) for process heat of less than $250^{\circ} \mathrm{C}$;

- Solar heating systems (advanced parabolic trough and linear Fresnel) for process heat of less than $400^{\circ} \mathrm{C}$; and

- Solar heating systems (central receiver) for thermochemistry heat of more than $750^{\circ} \mathrm{C}$.

Furthermore, resource mapping is required in the short term and standards and testing facilities need to be established and supported, not only for the prioritised technological systems, but also for 


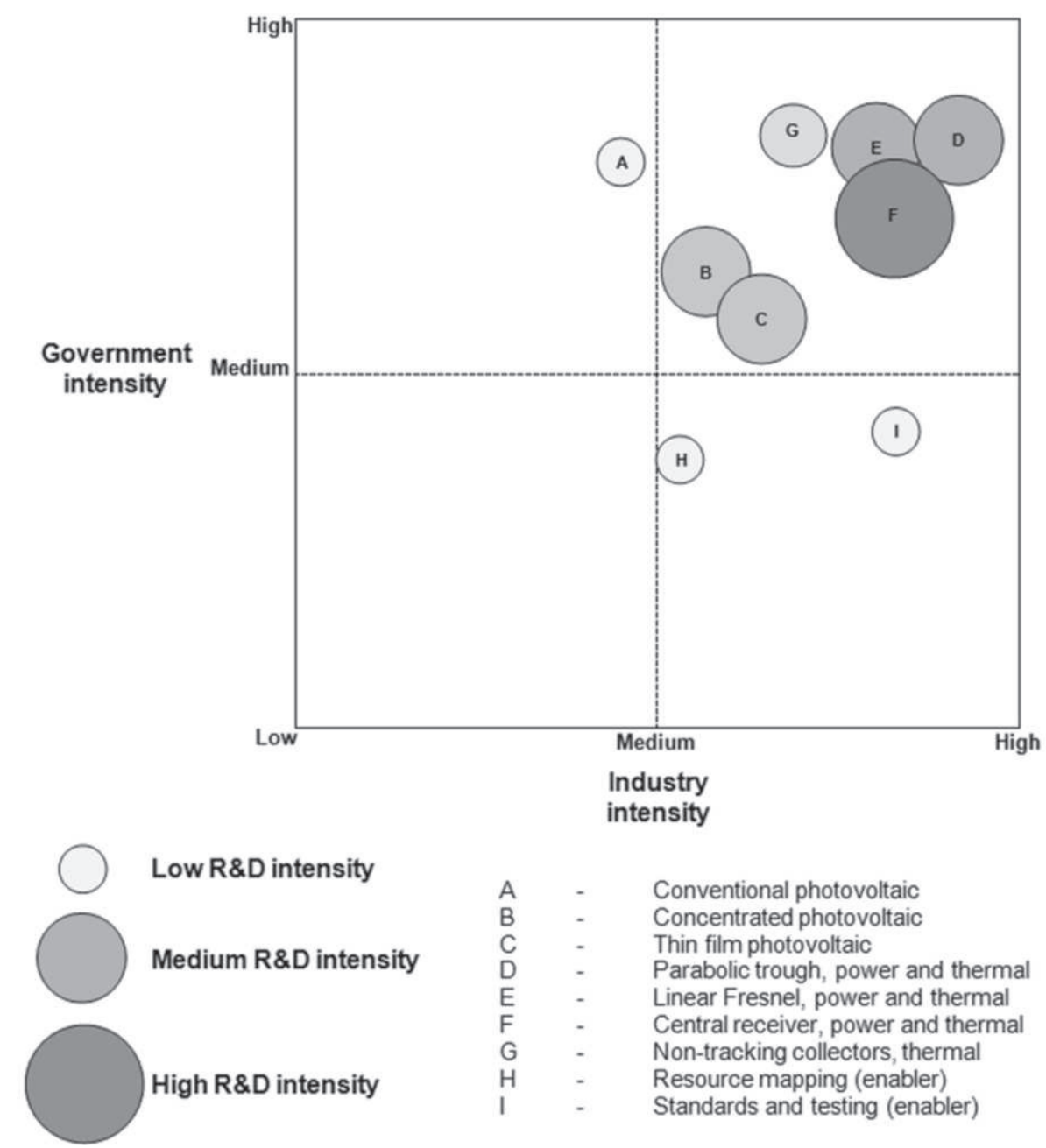

Figure 17: Analyses of the technological platforms in terms of government, industry and R\&D intensities

those that have already been commercialised and require less $R \& D$ interventions.

\subsection{The next ten years - The short to medium term}

In the short to medium term $R \& D$ resources need to be directed on a continual basis to support the four prioritised and other technological systems that are in the commercialisation phase:

- CSP systems for power and thermal applications: Optimise receiver system technologies for products and manufacturing (central receivers); expansion of existing system design, simulation and optimisation capabilities, including receiver structure and tracking systems, and dry and hybrid cooling in the power block; development of appropriate education and training programmes; and establishing R\&D facilities for improved and new generation absorber and storage technologies.

- Thermal applications: System optimisation research projects for specific applications, especially for process heat where a significant contribution can be made.
The proposed five and ten year activities were reviewed and benchmarked against the outcomes of two workshops: the first a CSP workshop held on 11 December 2009, where $R \& D$ requirements were discussed; and a second workshop on 19 February 2010, where stakeholders in the solar energy field (government, industry and the research institutions) held a strategic conversation about the proposed SETRM.

From an evaluation of the comparisons of the various outcomes of the proposed SETRM and the workshops, five definitive solar technology system focus areas can be identified, namely:

1. Solar Resource Assessment;

2. Photovoltaic Systems (not addressed in this paper);

3. Concentrating Solar Power Systems;

4. Industrial Solar Heating and Cooling; and

5. National coordination and collaborative demonstration facilities.

For the practical implementation of the SETRM the government is investigating further the structure that should be created to accommodate the various 
activities of the SETRM within these technology system focus areas.

\section{Notes}

1. Active solar technologies are employed to convert solar energy into usable heat or electricity, cause airmovement for ventilation or cooling, or store heat for future use. Active solar systems use electrical or mechanical equipment, such as pumps and fans, to increase the usable heat in a system.

2. Passive solar technologies convert sunlight into usable heat, cause air-movement for ventilation or cooling, or store heat for future use, without the assistance of other energy sources.

\section{Acknowledgements}

The authors wish to thank the team members of the larger DST project that contributed to the development of the SETRM, and in particular those individuals that provided meaningful inputs to improve and finalise the SETRM document: Wikus van Niekerk of Stellenbosch University, Thomas Roos of the CSIR, and Dieter Holm and Johann Basson in their private capacities. The authors are further appreciative of the numerous participants of the workshops, and those individuals in the public and private sectors that availed themselves for personal interviews and consultations; without these engagements the SETRM would not have been possible. Finally, the authors express their gratitude towards the DST, for providing the financial support, and the CSIR, for coordinating and facilitating the larger project.

\section{References}

Banks, D., Shäffler, J., 2006. The potential contribution of renewable energy in South Africa. Sustainable Energy \& Climate Change Project (SECCP), Earthlife Africa, Available from: www. earthlife.org.za.

Brent, A.C., Hietkamp, S., Wise, R.M., O'Kennedy, K., 2009. Estimating the carbon emissions balance for South Africa. South African Journal of Economic and Management Sciences, 12 (3): 263-279.

Department of Minerals and Energy (DME), 2006. Digest of South African energy statistics. Available from: www.energy.gov.za/files/media/ explained/2006 Digest PDF version.pdf.

Department of Science and Technology (DST), 2010. Establishment of a Centre of Competence in Solar Energy. CSIR project no. 06000/ 0NRDE/JZRDE02, Pretoria.

Edkins, M., Winkler, H., Marquard, A., 2009. Large-scale rollout of concentrating solar power in South Africa. Energy Research Centre, Univer-sity of Cape Town, Available from: www.erc.uct. ac.za.

Electricity Advisory Committee (EAC), 2009. Keeping the lights on in a new world. Available from: www.oe.energy.gov/eac.htm.

European Renewable Energy Research Centres (EUREC) Agency, 2009. Research priorities for renewable energy technology: By 2020 and beyond. Brussels, Available from: www.eurec. be/component/option, com_docman/task,doc_view/gid,540/.
Fluri, T.P., Meyer, A.J., Swanepoel, R., Rautenbach, K., Arai, A.W., Fakir, M.S., van Niekerk, J.L., 2008. Renewable energy study for: MeerKAT. Final report, Centre for Renewable and Sustainable Energy Studies, Stellenbosch Uni-versity.

Government of South Africa, 2009. Clean technology fund investment plan for South Africa, Review draft. Available from: www.climateinvestmentfunds.org/cif/ sites/climateinvestmentfunds.org/files/ctf_south_africa investment_plan_revised_110909.pdf.

Haw, M., Hughes, A., 2007. Clean energy and dev-elopment for South Africa: Scenarios. Energy Research Centre (ERC), University of Cape Town, British High Commission South Africa, Available from: www.erc. uct.ac.za.

Maia, J., 2009. The role of IDC in the financing of renewable energy projects with a focus on CSP. CSP workshop, Development Bank of Southern Africa, Midrand.

Marquard, A., Merven, B., Tyler, E., 2008. Costing a 2020 target of $15 \%$ renewable electricity for South Africa. Energy Research Centre (ERC), University of Cape Town, Available from: www. erc.uct.ac.za/ Research/publications/08-Mar-quardetal-costing a_2020_target.pdf.

Meyer R, 2010. Concentrated solar power. Lecture slides, Centre for Renewable and Sustainable Energy Studies, Stellenbosch University.

National Academy of Engineering (NAE), 2004. The hydrogen economy: Opportunities, costs, barriers, and $R \& D$ needs. Committee on Alternatives and Strategies for Future Hydrogen Production and Use, Board on Energy and Environmental Systems, Division on Engineer-ing and Physical Sciences, National Academies Press, Available from: www.nap.edu/openbook .php?isbn=0309091632

National Energy Regulator of South Africa (NERSA), 2009. NERSA decision on renewable energy feedin tariffs (REFITs) Phase II. Media statement 2 November, Pretoria, Available from: www.nersa.org. za/UploadedFiles/News/Media\%20statement\%20NE RSA\%20Decision\%20on\%20REFIT\%20Phase\%202 \%20-021109. pdf.

Pitz-Paal, R., Dersch, J., Milow, B., 2005. European Concentrated Solar Thermal Road-mapping. European Commission, $6^{\text {th }}$ Framework Programme, SES6-CT-2003-502578, Available from: www.vgb. org/data/vgborg_Forschung/ roadmap252.pdf.

Renewable Energy Policy Network for the 21st Century (REN21), 2009. Renewable Global Status Report: 2009 Update. REN21 Secretariat, Paris, Available from: www.ren21.net/globalstatusreport/.

Roos, T., 2009. South African CSP industrial and manufacturing potential - components, subsystems or systems. CSP workshop, Development Bank of Southern Africa, Midrand.

Sargent and Lundy Consulting Group, 2003. Assessment of parabolic trough and power tower solar technology cost and performance forecasts. National Renewable Energy Lab-oratory (NREL) SL-5641, Prepared for Department of Energy, Chicago, Illinois.

Scenario Building Team (SBT), 2007. Long term mitigation scenarios: Technical summary. Department of Environmental Affairs and Tourism, Pretoria, South 
Africa, Available from: www.environment.gov.za/ HotIssues/2008/LTMS/LTMS.html.

Sebitosi, A.B., Pillay, P., 2008. Renewable energy and the environment in South Africa: A way forward. Energy Policy, 36: 3312-3316.

Shipley, A., Hampson, A., Hedman, B., Garland, P., Bautista, P., 2009. Combined heat and power: Effective energy solutions for a sustainable future. Oak Ridge National Laboratory, Oak Ridge, Tennessee, Available from: www1.eere. energy.gov/ industry/distributedenergy/pdfs/chp_report_12-08. pdf.

Steinfeld, A., 2005. Solar thermochemical production of hydrogen: A review. Solar Energy, 78 (5): 603-615.

United Nations Environmental Programme (UNEP), 2009. Decoupling and sustainable resource management: Towards a conceptual framework. UNEP International Panel for Sustainable Resource

Management, Paris, Available from: www.unep.fr/ scp/rpanel/publications/.

Vannoni, C., Battisti, R., Drigo, S., 2008. Potential for solar heat in industrial processes. Booklet IEA SHC Task 33/IV, CIEMAT, Madrid.

Weber, E.R., 2009. The future of solar energy. Key note address, Solar World Congress, Sandton City, Available from: www.solarworldcongress 2009.com/ plenarypresentations.html.

Weiss, W., Bergmann, I. and Stelzer, R., 2009. Solar heat worldwide - Markets and contribution to the Energy Supply 2007. IEA Solar Heating \& Cooling Programme, Paris.

While Wyld Group (WWG), McLennan Magasanik Associates (MMA), 2008. High temperature solar thermal technology roadmap. Sandring-ham, Victoria, Available from: www.wyldgroup. com.au.

Winkler, H., Mukheibir, P., Mwakasonda, S., Garg, A., Halsneas, K., 2007. Electricity supply options, sustainable development and climate change priorities: Case studies for South Africa. UNEP Risoe Centre on Energy, Climate Change and Sustainable Development, Denmark, Available from: www.erc.uct.ac.za.

Winkler, H., Hughes, A., Haw, M., 2009. Technology learning for renewable energy: Implications for South Africa's long-term mitigation scenarios. Energy Policy, 37 (11): 4987-4996.

World Bank, 2009. Clean technology fund. Available from: http://go.worldbank.org/SG8NY Y3DK0.

Received 16 September 2010; revised 19 April 2011 